\title{
Monetary and fiscal factors in nominal interest rate variations in Sri Lanka under a deregulated regime
}

Biswajit Maitra

Correspondence:

b_moitra@yahoo.com

Department of Economics,

University of Gour Banga, Malda,

West Bengal, India

\begin{abstract}
Background: This paper examines the role of monetary and fiscal factors in interest rate variations in Sri Lanka under its deregulated regime of interest rates. In addition the paper also examines the role of monetary factors in the variation of interest rates, using a quarterly dataset for the post-global recession period, when the exchange rate is determined by market forces.
\end{abstract}

Results: Empirical analysis uses a dataset of nominal interest rates, money growth, income growth, changes in nominal exchange rate, and budget deficit. From the methodological point of view the paper involves vector autoregression model and Wald tests of Granger causality, followed by impulse response analysis while stationarity and the order of integration of the selected variables are confirmed involving the augmented Dickey-Fuller and the Phillips-Perron unit-root tests.

Results: The paper confirms that both monetary and fiscal factors have significant effects on the variations of interest rates. Money growth triggers an increase in interest rates, which supports the Fisher equation view, while income growth has a negative impact. Budget deficit causes a rise in interest rates, but the role of the exchange rate is found to be almost insignificant, probably due to including exchange rate series that cover both the pegged and market-based regimes of exchange rates. The second part of the analysis, using a quarterly dataset for the post-global recession period, further establishes the positive impact of M2 money growth and income growth on interest rates. In this case, exchange rate depreciation causes an increase in interest rates.

Conclusions: The significant role of monetary and fiscal factors in interest rate variations implies it would be possible to manage interest rates through a judiciary management of monetary and fiscal policies.

Keywords: Nominal interest rate, Money growth, Income growth, Exchange rate, Budget deficit, Vector autoregression

JEL codes: E43, E12

\section{Springer Open}

\section{Background}

Interest rates play a key role in the transmission of the monetary policy. Nevertheless, they also have a significant role in the execution of fiscal policy. Identifying their behavior thus helps accomplish the desired objective of these policies. Economic theory indicates

(C) The Author(s). 2017 Open Access This article is distributed under the terms of the Creative Commons Attribution 4.0 International License (http://creativecommons.org/licenses/by/4.0/), which permits unrestricted use, distribution, and reproduction in any medium, provided you give appropriate credit to the original author(s) and the source, provide a link to the Creative Commons license, and indicate if changes were made. 
interest rate variations depend on monetary, fiscal, and some external factors. However, theoretical studies find mixed evidence on the relationship between the interest rate and its determinants. Empirical research often helps specify the exact relations for the concerned countries, which is useful in the formulation of monetary policies. Consequently, this paper identifies how nominal interest rate variations in Sri Lanka are related to the few monetary and fiscal factors described in the economics literature.

In Sri Lanka, interest rate variations were extremely low until the early 1980s. At that time due to inward looking economic policies and direct regulations there was a little room for interest rates to vary. Moreover, at that time, the financial sector was not developed. However, Sri Lanka initiated a structural reform policy in 1977 and embarked on a number of initiatives to develop its financial sector. Interest rates were then deregulated. The flexible exchange rate regime replacing the pegged exchange rate in Sri Lanka was initiated in January 2001. The reform measures resulted in markedly improved financial sector performance, as demonstrated by the national the financial soundness indicators.

Variations of interest rates in Sri Lanka under regulated and deregulated regimes are presented in the time plot of the 91-day treasury bills (TBs) rate shown in Fig. 1. The figure reflects the variations were very low until the early 1980s, but became spectacular afterwards. The relatively higher interest rates during 1988-1995 were perhaps due to the anti-inflationary policy stance of the period. Further, higher interest rate over the periods of Asian financial crisis of 1997-1998 and the global financial recession of 2007-2008 reflect the policy stance of the Central Bank of Sri Lanka (CBSL) for crisis recovery.

Only few studies (Cooray 2002; Jayasinghe and Udayaseelan 2010; Amarasekara 2005) analyze the behavior of interest rates in Sri Lanka (details are presented in "Brief literature review" section). To the best of my knowledge, the determinants of interest rates in Sri Lanka are not hitherto identified. Consequently, this paper confirms the role of monetary and fiscal factors in the variations of nominal interest rates in Sri Lanka under the deregulated regime. Specifically, using an annual time series dataset, the paper examines the role of money growth, income growth, changes in nominal exchange rate, and budget deficit in the variations in nominal interest rates for 19832015. Furthermore, based on a quarterly dataset of the post-global financial recession period, when the market-based exchange rate regime was initiated, the role of monetary factors in the variations of interest rates are also studied.

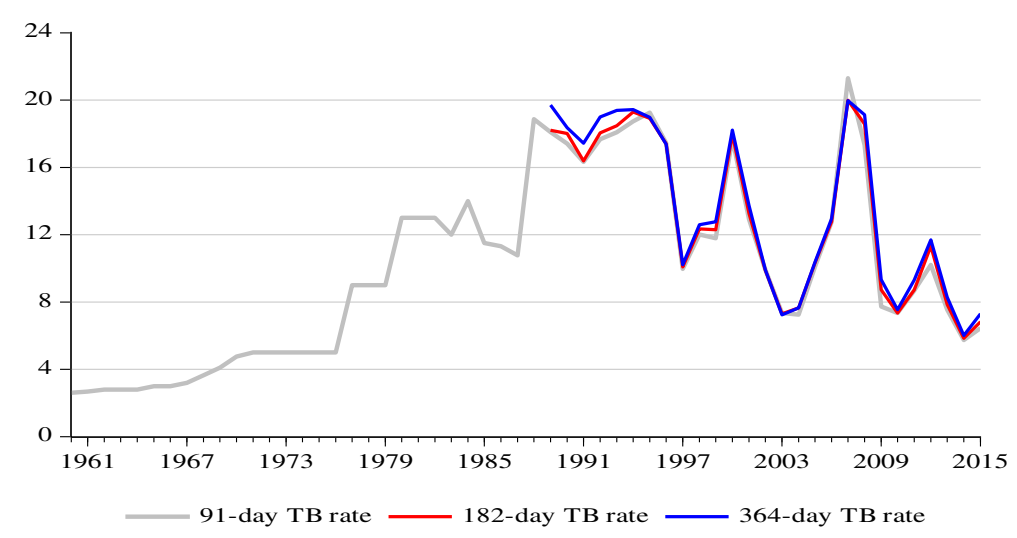

Fig. 1 Time plot of annual interest rates in Sri Lanka. Source: author's representation of CBSL data 
Notably, the period 1983-2015 witnessed a paradigm shift in the exchange rate regime-from a pegged to an independent float regime. Specifically, at the time of gaining its independence in 1948, a fixed exchange rate system was operative, with the Sri Lankan rupee being pegged to the Indian rupee. In 1950, the rupee became the standard of monetary value (and was fixed at $0.88 \mathrm{~g}$ of gold) and the exchange rate was Rs 13.33 for one British pound and Rs 4.77 per one US dollar. This system was again replaced by a dual exchange rate system in 1968 .

The dual exchange rate system was then replaced by a managed floating system in 1977. Under this system, the exchange rate was linked to a basket of currencies. The managed floating exchange rate system was finally replaced by an independent float regime on January 23, 2001. The CBSL took a landmark step towards liberalizing the foreign exchange market by allowing commercial banks to determine the exchange rate according to the market forces of currency demand and supply. However, the CBSL retained its power to intervene on the foreign exchange market when required.

The efficacy of the monetary policy and its transmission through the interest rate channel depend largely on the exchange rate system. The Mundell-Fleming model (Fleming 1962; Mundell 1963) of open economy macroeconomics testifies that the monetary policy of a small open economy becomes effective when the economy adopts a flexible exchange rate system. Further, under the flexible exchange rate system, the foreign exchange market could play significant role in interest rate variations.

In fact, the first part of this study, covering the period 1983-2015, includes both the pegged and independent float regimes of the exchange rate in Sri Lanka. To account for the impact of the change in the exchange rate regime on the relation among interest rates and the selected determinants over this period, a dummy variable is used. On the other hand, in the second part of the study, which covers the post-global financial recession period, the independent float regime of exchange rate has been operating. Therefore, the second part of the analysis excludes the global financial recession period for a number of reasons. During this recession, the monetary policies of numerous countries were deviated to a crisis management trail. Although the crisis impacted the national macroeconomic policies over short period, the stability of the financial system was not affected. Unlike some European countries, no banks in Sri Lanka collapsed. One of the important reasons for the minimal impact of the crisis is the capital account not being fully liberalized. However, some short-term foreign investments were withdrawn. The foreign funds invested in Sri Lankan Treasury bills and long-term bonds were also withdrawn. To rescue the economy from the impasse of the crisis, some policy measures were thus initiated, and the CBSL intervened on the foreign exchange market to prevent the depreciation of the national currency.

The remainder of this paper is structured as follows. In the following section, 'Theoretical background and a brief literature review' related to the variation and determination of interest rates are presented. The section 'Methods' puts forward the variables, data, and methodology; followed by section 'Results and discussions'. The paper ends with "Conclusions". 


\section{Theoretical background and a brief literature review}

Among the monetary factors affecting interest rate, the money supply is regarded as a potential determinant, although economic literature proposes contradictory theoretical relationships between the money supply and interest rate. One of the conventional views is the liquidity effect view, which postulates a negative relation between money and interest rate. That is, an unexpected growth of money supply lowers interest rates (to maintain equilibrium on the money market), with a unidirectional causality running from money supply to the interest rate. Keynes (1936) explains a transmission mechanism through which the interest rate variations due to change in investment, output, and employment in an economy can be analyzed. Conversely, based on the Fisher equation (Fisher 1930), a positive relationship exists between money growth and interest rate. Specifically, the Fisher equation states that the nominal interest rate equals the real interest rate plus the expected rate of inflation. If the real interest rate remains fixed and the money supply increases continuously, the price level or inflation increase, which in turn also increases the expected inflation. A higher expected inflation eventually causes the nominal interest rate to increase as well. Therefore, if the Fisher equation is found valid, there may be a positive causal impact of money supply on the nominal interest rate.

Friedman posits some limitations to the above theoretical propositions, arguing that the Keynesian explanation cannot explain the situations where interest rate displays a positive response to money supply growth. On the other hand, the negative sensitivity of the interest rate to money growth, often found empirically, cannot be explained by the Fisher equation. Therefore, Friedman reformulates the theory to explain both the positive and negative sensitivities of the interest rate caused by money supply variations. He hypothesized that a fall or rise in interest rates depends on the relative growth of the money supply and anticipated nominal income, such that interest rates rise over time when the money supply growth rate increased provided this latter rate exceeds anticipated growth rate of nominal income. Conversely, interest rates fall due to money growth when the rate of money supply growth is below the anticipated nominal income growth rate. In fact, if the money supply is equal to the nominal income rate, the interest rate remains unchanged. A more detailed explanation of this theoretical proposition, as well as an empirical verification, can be found in Maitra (2017).

Economic literature also holds the view that interest variations are positively related to the income level of the economy. Specifically, a higher national income or income growth causes a rise in the demand for money, which leads the interest rate to rise. Further, in a flexible exchange rate system, interest rate variations are related to capital flows and exchange rate movements. A decrease in the exchange rate usually lowers the demand for domestic financial assets and discourages foreign investors to invest in an economy. Therefore, the continuous depreciation of a currency may reduce foreign investment. A fall in foreign investment means a fall in the supply of funds which, as a consequence, increases the interest rate. Furthermore, the relationship between interest and expected exchange rates is analyzed by the uncovered interest rate parity (UIP) theory, where the domestic interest rate equals the foreign interest rate plus the increase in the expected value of the foreign currency. UIP theory shows that expected currency depreciation may cause the domestic interest rate to rise. Nevertheless, in an open economy, external factors such as the foreign interest rate and price levels may 
influence the domestic interest rate, where the exchange rate transmits these external impulses to the domestic economy. Therefore, the exchange rate is an important determinant of the interest rate, particularly in a financially integrated open economy.

On the other hand, interest rate variations also depend on fiscal policy instruments such as public debt, budget deficit, or fiscal deficit. There is a controversy among economists whether deficit increases the interest rate. Keynesian theory (Keynes 1936) posits that changes in budget deficit influence the interest rates. Specifically, an increase in the budget deficit or public debt causes the interest rate to rise. However, some economists argue that the expected budget deficit or government debt, instead of the present, affects the real long-term interest rate (Kameda 2014; Laubach 2009; Engen and Hubbard 2004; Quigley and Porter-Hudak 1994; Thorbecke 1993; Wachtel and Young 1987; Feldstein 1986). Conversely, the Ricardian equivalence argues that deficit does not matter. Moreover, the empirical research by Plosser $(1982,1987)$ and Evans (1987) fail to establish any significant positive relationship between budget deficits on the long-term interest rate. Therefore, the question whether budget deficits affect the interest rate is still inconclusive. Aisen and Hauner (2008) suggest the effect of budget deficits on the interest rate depends on several factors such as the degrees of capital mobility, of domestic or external financing for deficits, of interest rates being market determined. Among the few studies on this issue in Sri Lanka, Cooray (2002) studies whether the Fisher effectis valid. Using annual time series, the study finds evidences for the Fisher effect. Jayasinghe and Udayaseelan (2010) further examine the Fisher hypothesis in Sri Lanka involving annual, quarterly, and monthly time series for 1978-2007. However, the study fails to produce any evidence supporting the Fisher equation. Amarasekara (2005) studies the interest rate pass-through in Sri Lanka using daily datasets, including the repo, reverse repo, repo auction, and the money rates. The study also examines the size and speed of the pass-through from policy to call money market rates and that from the call money to commercial bank retail interest rates. The main findings are that the CBSL policy decisions are efficiently transmitted to the short end of the money market within days. The pass-through from policy rates to the call money rate is almost complete, but that from the call money rate to both lending rates and deposit rates of commercial banks is sluggish and incomplete. Further, no evidence of asymmetry in the passthrough over the different phases of the interest rate cycle is found. Moreover, few studies (Maitra and Debnath 2015; Amarasekara 2008) report that interest rate variations in Sri Lanka have significant impact on macroeconomic variables such as income and price level, suggesting the monetary policy is effective.

Several studies address the determinants of interest rates in Asian countries, such as Maitra (2017), Abubakar and Sivagnanam (2016), Bhattacharya et al. (2008), Bhanumurthy and Agarwal (2003), Dua and Pandit (2002), Nachane (1988), and Paul (1984) for the Indian economy. These studies differ significantly regarding time span, data frequencies, modeling, and methodological aspects, their findings being thus mixed but generating significant discussions due to policy implications. On the other hand, Goh and Alias (2002) and Ahmad and Karim (2011) study the determinants of interest rates in Malaysia, Ahn (1994) focuses on Korea and Singapore, while He et al. (2014) study interest rate determination in China. 
Apart from studies on Asian countries, a substantial volume of research examines the determinants of interest rates for many other developed and developing countries. Among these studies, Asamoah and Adu (2016) identify the determinants of the bank lending rate in Ghana for 1970-2013. Their empirical analysis confirms a long-run equilibrium relationship among the average lending rate charged by commercial banks and nominal money supply, income, price level, government fiscal balance, and exchange rate. Based on the estimated autoregressive distributed lag (ARDL), fully-modified ordinary least squares, and dynamic ordinary least squares models, the nominal exchange and monetary policy rates are shown tohave significant contemporaneous effects on the lending interest rate. Aksoy and León-Ledesma (2005) examine the long-term relationships between monetary policy indicators and real output in the U.S. and the U.K., but find no evidence of such relationships, nor a significant or stable long-term relationship between short term interest rates and real output for the sub-samples.

Edwards and Khan (1985) present a model for determining the interest rate in developing countries. The empirical validity of this model is studied using dataset for Colombia and Singapore. They report that, in Colombia, both foreign and domestic factors affect nominal interest rates, while domestic interest rates in Singapore are fully determined by the foreign interest rates and exchange rate relationship between money supply and interest rates in 19 developed and 13 developing countries is studied by Monnet and Weber (2001). They find evidence of both the liquidity effect and support for the Fisher equation. Moreover, Turtelboom (1991) studies the determinants of interest rates for some African countries, while Howe and Pigott (1991) identify the determinants of long-term interest rates for several industrial countries. The determination of real interest rates in the European countries over the period 1959-1990 is studied by Knot (1995), while Akhtar (1995) presents a survey of empirical studies on the effects of monetary policy on long-term interest rates.

Additionally, Caporale and Pittis (1997) develop a theoretical model and analyze interest rate determination in the United States, Japan, Germany, France, and Switzerland, finding that the behavior of interest rates reflects both internal and external influences in all five countries. Estimating a structural vector autoregression (VAR) model, Bernanke and Mihov (1998) enquire whether the liquidity effect view and longrun monetary neutrality are consistent in a model of the market for bank reserves under Fed's operative regime. They find evidence for rejecting either the liquidity effect or long-run neutrality. Schabert (2005) analyzes the relation between interest rate targets and money supply in the rational expectations equilibrium of a standard cashin-advance model. The study reports that an accommodating money supply tends to destabilize equilibrium sequences if the interest rate target rule is forward-looking and active. Conversely, a sufficiently inertial interest rate target can be implemented by stabilizing the money supply policy.

\section{Methods}

\section{Variables, data, and methodology}

The empirical analysis in this paper involves annual and quarterly time series datasets. The dataset of annual time series includes interest rates on 91- and 364-day TBs as 
measure of the nominal interest rate. Money growth (both M1 and M2), real gross domestic product (GDP) growth (as measure of income growth), and changes of the nominal exchange rate of the Sri Lankan rupee/US dollar are used as the monetary determinants of the interest rate. Budget deficit as a percentage of GDP is used as the fiscal determinant, while a dummy variable Dt examines the impact of change in the exchange rate regime on the relation to be studied; its value is 0 for the fixed exchange rate regime and 1 for flexible regime. The annual dataset covers 1983-2015, although the time span of 364-day TBs is 1989-2015. On the other hand, the quarterly dataset includes the call money rate and interest rates on 364-day TBs, deseasonalized quarterly real GDP growth, deseasonalized real M1, M2 money supply growth, and quarterly change in nominal exchange rate over the post-global recession period (2009:Q1-2016:Q2). Quarterly series of budget deficits or any other suitable series for fiscal determinants are not available and, therefore, the analysis using the quarterly dataset is limited to monetary factors. The symbolic representation of variables is presented in Table 1.

The time series properties, namely the stationary and order of integration of the selected variables, need to be confirmed before selecting an appropriate econometric model for analysis. Among the various tests developed for studying stationarity and the order of integration, this study chose the augmented Dickey and Fuller (1981, henceforth ADF) and Phillips and Perron (1988, henceforth PP) unit-root tests. In the event of stationarity of selected variables at the level, underlying dynamics of interest rates with money growth, income growth, changes in exchange rate, and budget deficit have been studied by estimating an unrestricted vector autoregression (VAR) model. The causal impact of selected monetary and fiscal determinants on interest rates from the VAR model has further been studied using the Wald test of Granger causality. Further, impulse response analysis is used to access the dynamic movements of interest rates due to each of the endogenous innovations in the VAR. A more detailed technical account of these popular methodologies is not presented in this applied research due to space consideration.

Table 1 Variables and representation

\begin{tabular}{lll}
\hline Variables & Specification & Representation \\
\hline nominal interest rate & annual rate of interest on 91-day TBs & $i_{\mathrm{a} 1 \mathrm{t}}$ \\
& annual rate of interest on 364-day TBs & $\mathrm{i}_{\mathrm{a} 2 \mathrm{t}}$ \\
& quarterly series of call money rate & $\mathrm{i}_{\mathrm{q} \text { 1t }}$ \\
& quarterly series of interest on 364-day TBs & $\mathrm{i}_{\mathrm{q} 2 \mathrm{t}}$ \\
budget deficit & budget deficit as the percentage of GDP & $\mathrm{B}_{\mathrm{t}}$ \\
money supply growth & annual series of real M1 money supply growth & $\mathrm{M}_{\text {1at }}$ \\
& annual series of real M2 money supply growth & $\mathrm{M}_{2 \mathrm{at}}$ \\
& quarterly series of real M1 money growth & $\mathrm{M}_{1 \mathrm{qt}}$ \\
rate of change of exchange rate & quarterly series of real M2 money growth & $\mathrm{M}_{2 \mathrm{qt}}$ \\
rate of change of annual exchange rate & $\mathrm{E}_{\mathrm{at}}$ \\
real income growth & rate of change of quarterly exchange rate & $\mathrm{E}_{\mathrm{qt}}$ \\
& growth of annual real GDP at factor cost & $\mathrm{Y}_{\mathrm{at}}$ \\
& growth of quarterly real GDP at factor cost & $\mathrm{Y}_{\mathrm{qt}}$ \\
\hline
\end{tabular}

Source: Author's representation 
However, the estimable form of the VAR model using interest rate, selected monetary, and fiscal determinants is presented below:

$$
\begin{aligned}
& \begin{aligned}
1_{\mathrm{a} 1 \mathrm{t}}= & \alpha_{1}+\sum_{\mathrm{i}=1}^{\mathrm{n}} \beta_{1 \mathrm{i}} \mathrm{i}_{\mathrm{a} 1 \mathrm{t}-\mathrm{i}}+\sum_{\mathrm{i}=1}^{\mathrm{n}} \theta_{1 \mathrm{i}} \mathrm{M}_{\mathrm{at}-\mathrm{i}}+\sum_{\mathrm{i}=1}^{\mathrm{n}} \rho_{1 \mathrm{i}} \mathrm{E}_{\mathrm{at}-\mathrm{i}}+\sum_{\mathrm{i}=1}^{\mathrm{n}} \gamma_{1 \mathrm{i}} \mathrm{Y}_{\mathrm{at}-\mathrm{i}} \\
& +\sum_{\mathrm{i}=1}^{\mathrm{n}} \delta_{1 \mathrm{i}} \mathrm{B}_{\mathrm{t}-\mathrm{i}}+\mathrm{D}_{\mathrm{t}}+\varepsilon_{1 \mathrm{t}}
\end{aligned} \\
& M_{a t}=\alpha_{2}+\sum_{i=1}^{n} \beta_{2 i} M_{a t-i}+\sum_{i=1}^{n} \theta_{2 i} i_{a 1 t-i}+\sum_{i=1}^{n} \rho_{2 i} E_{a t-i}+\sum_{i=1}^{n} \gamma_{2 i} Y_{a t-i} \\
& +\sum_{\mathrm{i}=1}^{\mathrm{n}} \delta_{2 \mathrm{i}} \mathrm{B}_{\mathrm{t}-\mathrm{i}}+\mathrm{D}_{\mathrm{t}}+\varepsilon_{2 \mathrm{t}} \\
& E_{a t}=\alpha_{3}+\sum_{i=1}^{n} \beta_{3 i} E_{a t-i}+\sum_{i=1}^{n} \theta_{3 i} Y_{a t-i}+\sum_{i=1}^{n} \rho_{3 i} i_{a 1 t-i}+\sum_{i=1}^{n} \gamma_{3 i} M_{a t-i} \\
& +\sum_{\mathrm{i}=1}^{\mathrm{n}} \delta_{3 \mathrm{i}} \mathrm{B}_{\mathrm{t}-\mathrm{i}}+\mathrm{D}_{\mathrm{t}}+\varepsilon_{3 \mathrm{t}} \\
& \mathrm{Y}_{\mathrm{at}}=\alpha_{4}+\sum_{\mathrm{i}=1}^{\mathrm{n}} \beta_{4 \mathrm{i}} \mathrm{Y}_{\mathrm{at}-\mathrm{i}}+\sum_{\mathrm{i}=1}^{\mathrm{n}} \theta_{4 \mathrm{i}} \mathrm{i}_{\mathrm{a} 1 \mathrm{t}-\mathrm{i}}+\sum_{\mathrm{i}=1}^{\mathrm{n}} \rho_{4 \mathrm{i}} \mathrm{M}_{\mathrm{at}-\mathrm{i}}+\sum_{\mathrm{i}=1}^{\mathrm{n}} \gamma_{4 \mathrm{i}} \mathrm{E}_{\mathrm{at}-\mathrm{i}} \\
& +\sum_{\mathrm{i}=1}^{\mathrm{n}} \delta_{4 \mathrm{i}} \mathrm{B}_{\mathrm{t}-\mathrm{i}}+\mathrm{D}_{\mathrm{t}}+\varepsilon_{4 \mathrm{t}} \\
& \mathrm{B}_{\mathrm{t}}=\alpha_{5}+\sum_{\mathrm{i}=1}^{\mathrm{n}} \beta_{5 \mathrm{i}} \mathrm{B}_{\mathrm{t}-\mathrm{i}}+\sum_{\mathrm{i}=1}^{\mathrm{n}} \theta_{5 \mathrm{i}} \mathrm{i}_{\mathrm{a} 1 \mathrm{t}-\mathrm{i}}+\sum_{\mathrm{i}=1}^{\mathrm{n}} \rho_{5 \mathrm{i}} \mathrm{M}_{\mathrm{at}-\mathrm{i}}+\sum_{\mathrm{i}=1}^{\mathrm{n}} \gamma_{5 \mathrm{i}} \mathrm{E}_{\mathrm{at}-\mathrm{i}} \\
& +\sum_{\mathrm{i}=1}^{\mathrm{n}} \delta_{5 \mathrm{i}} \mathrm{Y}_{\mathrm{at}-\mathrm{i}}+\mathrm{D}_{\mathrm{t}}+\varepsilon_{5 \mathrm{t}}
\end{aligned}
$$

where $\mathrm{i}_{\mathrm{a} 1 \mathrm{t}-\mathrm{i}}, \mathrm{M}_{\mathrm{a} 1 \mathrm{t}-\mathrm{i}}, \mathrm{E}_{\mathrm{at}-\mathrm{i}}, \mathrm{Y}_{\mathrm{at}-\mathrm{i}}$, and $\mathrm{B}_{\mathrm{t}-\mathrm{i}}(i=1,2, \ldots, \mathrm{n})$ are lagged series of $i_{\mathrm{a} 1 t}, \mathrm{M}_{\mathrm{a} 1 \mathrm{t}}$, $E_{a t}, Y_{a t}$, and $B_{t}$ series respectively. The optimum lag length, $n$, can be determined by the lag selection criterion, while $\varepsilon_{1 \mathrm{t}}, \varepsilon_{2 \mathrm{t}}, \varepsilon_{3 \mathrm{t}}, \varepsilon_{4 \mathrm{t}}$, and $\varepsilon_{5 \mathrm{t}}$ represent innovations that may be contemporaneously correlated but are uncorrelated with their own lagged terms and with all right-hand-side variables.

\section{Results and discussion}

The empirical analysis first studies the stationarity and order of integration of the selected series. The calculated values of the ADF and the PP unit-root tests are presented in Table 2, both test statistics failing to accept the null hypothesis of unit-root in each of the selected variables, even under annual and quarterly frequencies (with the appropriate assumption "intercept but no trend"). This means these series are stationary at level or I(0) stationary.

As each of the selected variables are I(0) stationary, an appropriate model for identifying the role of monetary and fiscal determinants in the interest rate variations would be the VAR model. As stated in the previous section, I estimate the VAR model separately for two annual interest rates, first with M1money growth, income growth, change

Table 2 Results of unit-root tests

\begin{tabular}{llllll}
\hline Annual Series & ADF Statistic & PP Statistic & Quarterly Series & ADF Statistic & PP Statistic \\
\hline $\mathrm{i}_{\mathrm{a} 1 \mathrm{t}}$ & $-3.125(0.04)$ & $-3.793(0.02)$ & $\mathrm{i}_{\mathrm{q} 1 \mathrm{t}}$ & $-4.653(0.00)$ & $-3.923(0.00)$ \\
$\mathrm{i}_{\mathrm{a} 2 \mathrm{t}}$ & $-4.421(0.00)$ & $-4.816(0.00)$ & $\mathrm{i}_{\mathrm{q} 2 \mathrm{t}}$ & $-3.168(0.03)$ & $-3.548(0.01)$ \\
$\mathrm{B}_{\mathrm{t}}$ & $-4.009(0.00)$ & $-4.745(0.00)$ & $\mathrm{M}_{1 \mathrm{qt}}$ & $-4.267(0.00)$ & $-4.226(0.00)$ \\
$\mathrm{M}_{1 \mathrm{at}}$ & $-4.914(0.00)$ & $-4.944(0.00)$ & $\mathrm{M}_{2 \mathrm{at}}$ & $-6.157(0.00)$ & $-6.413(0.00)$ \\
$\mathrm{M}_{2 \mathrm{at}}$ & $-4.858(0.00)$ & $-7.579(0.00)$ & $\mathrm{E}_{\mathrm{qt}}$ & $-3.460(0.01)$ & $-3.126(0.03)$ \\
$\mathrm{E}_{\mathrm{at}}$ & $-5.144(0.00)$ & $-5.143(0.00)$ & $\mathrm{Y}_{\mathrm{qt}}$ & $-4.408(0.00)$ & $-5.523(0.00)$ \\
$\mathrm{Y}_{\text {at }}$ & $-6.668(0.00)$ & $-6.661(0.00)$ & & & \\
\hline
\end{tabular}

Both ADF and PP tests have been conducted with the assumption "intercept but no trend" for the entire series. Values in parentheses indicate the probability of rejecting the null hypothesis on the unit root Source: Author's estimation 
of exchange rate, budget deficit, and the dummy variable. Then, the VAR is reestimated replacing M1 by M2 money growth (keeping other variables unaltered).Therefore, the VAR is estimated four times (Estimations 1-4). For Estimations 1 and 2, the targeted equations of interest rates are reported in Table 3. Similarly, the equations for Estimations 3 and 4 are reported in Table 4 . In these estimations, a lag length 3 is found to be optimum based on the Schwarz information criterion (SC). The reliability of each estimation has been checked using a battery of diagnostic tests, but not all results are reported due to space considerations.

Each of the four equations reported in Tables 3 and 4 reveals that both M1 and M2 money growth have a significant role in interest rate variations. Specifically, the oneperiod lagged money growth causes a rise in interest rates. This positive impact supports the Fisher equation view regarding the relation between money and interest rate. Lagged income growth, on the other hand, has a negative impact on interest rates, which is consistent with the positive impact of money growth in that an increase in income leads to a rise in the demand for money, which lowers interest rates. The results also reveal a significant positive impact of the budget deficit on interest rates, where a

Table 3 Dynamics of annual interest rates (M1 money growth is used)

\begin{tabular}{|c|c|c|c|c|c|c|c|}
\hline \multicolumn{4}{|c|}{ Targeted dependent variable $\mathrm{i}_{\mathrm{a} 1 \mathrm{t}}$ (of Estimation 1) } & \multicolumn{4}{|c|}{ Targeted dependent variable $\mathrm{i}_{\mathrm{a} 2 \mathrm{t}}$ (of Estimation 2) } \\
\hline Parameters & Estimates & t-values & Prob. & Parameters & Estimates & t-values & Prob \\
\hline$a_{1}$ & 0.184 & 3.467 & 0.00 & $a_{1}$ & 0.197 & 2.015 & 0.08 \\
\hline $\mathrm{i}_{\mathrm{a} 1 \mathrm{t}-1}$ & 1.055 & 5.175 & 0.00 & $\mathrm{i}_{\mathrm{a} 2 \mathrm{t}-1}$ & 1.113 & 4.350 & 0.00 \\
\hline $\mathrm{i}_{\mathrm{a} 1 \mathrm{t}-2}$ & -0.563 & -2.139 & 0.04 & $i_{a 2 t-2}$ & -0.359 & -1.089 & 0.31 \\
\hline $\mathrm{i}_{\mathrm{a} 1 \mathrm{t}-3}$ & -0.430 & -2.202 & 0.04 & $\mathrm{i}_{\mathrm{a} 2 \mathrm{t}-3}$ & -0.506 & -1.591 & 0.15 \\
\hline$M_{1 \text { at }-1}$ & 0.212 & 2.097 & 0.05 & $M_{1 \text { at }-1}$ & 0.282 & 2.339 & 0.05 \\
\hline$M_{1 \text { at }-2}$ & -0.435 & -3.139 & 0.00 & $\mathrm{M}_{1 \text { at }-2}$ & -0.383 & -2.209 & 0.06 \\
\hline$M_{1 \text { at }-3}$ & 0.281 & 2.967 & 0.00 & $M_{1 \text { at }-3}$ & 0.373 & 2.056 & 0.07 \\
\hline$Y_{a t-1}$ & 0.471 & 2.674 & 0.01 & $Y_{a t-1}$ & 0.473 & 2.018 & 0.08 \\
\hline$Y_{a t-2}$ & 0.075 & 0.520 & 0.60 & $Y_{a t-2}$ & 0.023 & 0.116 & 0.91 \\
\hline$Y_{a t-3}$ & -0.674 & -4.486 & 0.00 & $Y_{a t-3}$ & -0.818 & -3.036 & 0.01 \\
\hline$E_{a t-1}$ & 0.109 & 0.915 & 0.37 & $E_{a t-1}$ & 0.117 & 0.779 & 0.46 \\
\hline$E_{a t-2}$ & -0.292 & -2.626 & 0.01 & $E_{a t-2}$ & -0.268 & -2.077 & 0.07 \\
\hline$E_{a t-3}$ & 0.134 & 1.198 & 0.24 & $E_{a t-3}$ & 0.180 & 1.077 & 0.31 \\
\hline$B_{t-1}$ & 0.460 & 1.283 & 0.21 & $B_{t-1}$ & 1.042 & 1.534 & 0.16 \\
\hline$B_{t-2}$ & -1.340 & -2.994 & 0.00 & $B_{t-2}$ & -1.628 & -2.441 & 0.04 \\
\hline$B_{t-3}$ & 1.186 & 3.248 & 0.00 & $B_{t-3}$ & 1.314 & 1.781 & 0.11 \\
\hline$D_{t}$ & -0.052 & -3.652 & 0.00 & $D_{t}$ & -0.047 & -2.655 & 0.03 \\
\hline \multicolumn{4}{|c|}{$R^{2}=0.87, \overline{\mathrm{R}}^{2}=0.75$, F-statistic $=7.198$} & \multicolumn{4}{|c|}{$R^{2}=0.93, \bar{R}^{2}=0.77$, F-statistic $=6.03$} \\
\hline \multicolumn{4}{|c|}{$\begin{array}{l}\text { Wald test for Granger causality } \\
\text { Dependent Variable: } \mathrm{i}_{\mathrm{a} 1 \mathrm{t}}\end{array}$} & \multicolumn{4}{|c|}{$\begin{array}{l}\text { Wald test for Granger causality } \\
\text { Dependent Variable: } \mathrm{i}_{\mathrm{a} 2 \mathrm{t}}\end{array}$} \\
\hline Excluded & \multicolumn{2}{|c|}{ Wald test statistic $\left(x^{2}\right)$} & prob. & Excluded & \multicolumn{2}{|c|}{ Wald test statistic $\left(x^{2}\right)$} & prob \\
\hline$M_{\text {lat }}$ & \multicolumn{2}{|l|}{14.83} & 0.00 & $M_{\text {lat }}$ & \multicolumn{2}{|l|}{11.10} & 0.01 \\
\hline$Y_{\text {at }}$ & \multicolumn{2}{|l|}{20.63} & 0.00 & $Y_{a t}$ & \multicolumn{2}{|l|}{10.07} & 0.01 \\
\hline$E_{a t}$ & \multicolumn{2}{|l|}{9.05} & 0.02 & $E_{a t}$ & \multicolumn{2}{|l|}{6.29} & 0.09 \\
\hline$B_{t}$ & \multicolumn{2}{|l|}{14.13} & 0.00 & $\mathrm{~B}_{\mathrm{t}}$ & \multicolumn{2}{|l|}{8.14} & 0.04 \\
\hline All: & \multicolumn{2}{|l|}{36.58} & 0.00 & All: & \multicolumn{2}{|l|}{25.94} & 0.01 \\
\hline
\end{tabular}

Source: Author's estimation 
Table 4 Dynamics of annual interest rates (M2 money growth is used)

\begin{tabular}{|c|c|c|c|c|c|c|c|}
\hline \multicolumn{4}{|c|}{ Targeted dependent variable $\mathrm{i}_{\mathrm{a} 1 \mathrm{t}}$ (of Estimation 3) } & \multicolumn{4}{|c|}{ Targeted dependent variable $\mathrm{i}_{\mathrm{a} 2 \mathrm{t}}$ (of Estimation 4) } \\
\hline Parameters & Estimates & t-values & Prob. & Parameters & Estimates & t-values & Prob. \\
\hline$a_{1}$ & 0.152 & 3.377 & 0.00 & $a_{1}$ & 0.176 & 2.858 & 0.02 \\
\hline $\mathrm{i}_{\mathrm{a} 1 \mathrm{t}-1}$ & 0.992 & 5.397 & 0.00 & $i_{a 2 t-1}$ & 1.206 & 5.295 & 0.00 \\
\hline $\mathrm{i}_{\mathrm{a} \text { at }-2}$ & -0.550 & -2.119 & 0.05 & $\mathrm{i}_{\mathrm{a} 2 \mathrm{t}-2}$ & -0.722 & -2.105 & 0.07 \\
\hline $\mathrm{i}_{\mathrm{a} \text { at }-3}$ & -0.205 & -1.008 & 0.32 & $\mathrm{i}_{\mathrm{a} 2 \mathrm{t}-3}$ & -0.257 & -0.905 & 0.39 \\
\hline$M_{2 a t-1}$ & 0.263 & 2.528 & 0.02 & $M_{\text {2at-1 }}$ & 0.290 & 2.458 & 0.04 \\
\hline$M_{2 a t-2}$ & -0.231 & -1.837 & 0.08 & $M_{\text {2at }-2}$ & -0.280 & -1.991 & 0.08 \\
\hline$M_{2 a t-3}$ & 0.189 & 1.341 & 0.19 & $M_{2 a t-3}$ & 0.311 & 1.876 & 0.10 \\
\hline$Y_{a t-1}$ & 0.131 & 0.766 & 0.45 & $Y_{a t-1}$ & 0.139 & 0.664 & 0.52 \\
\hline$Y_{a t-2}$ & -0.128 & -0.865 & 0.39 & $Y_{a t-2}$ & -0.202 & -1.195 & 0.27 \\
\hline$Y_{a t-3}$ & -0.397 & -2.832 & 0.01 & $Y_{a t-3}$ & -0.568 & -3.086 & 0.01 \\
\hline$E_{a t-1}$ & 0.087 & 0.776 & 0.44 & $E_{a t-1}$ & 0.059 & 0.417 & 0.68 \\
\hline$E_{a t-2}$ & -0.171 & -1.639 & 0.12 & $E_{a t-2}$ & -0.205 & -1.754 & 0.12 \\
\hline$E_{a t-3}$ & 0.007 & 0.078 & 0.93 & $E_{a t-3}$ & -0.003 & -0.002 & 0.99 \\
\hline$B_{t-1}$ & 0.160 & 0.479 & 0.63 & $B_{t-1}$ & 0.454 & 0.810 & 0.44 \\
\hline$B_{t-2}$ & -0.530 & -1.718 & 0.10 & $B_{t-2}$ & -1.069 & -2.448 & 0.04 \\
\hline$B_{t-3}$ & 0.600 & 2.279 & 0.03 & $\mathrm{~B}_{\mathrm{t}-3}$ & 0.915 & 1.790 & 0.11 \\
\hline$D_{t}$ & -0.039 & -3.329 & 0.00 & $D_{t}$ & -0.037 & -2.312 & 0.05 \\
\hline \multicolumn{4}{|c|}{$R^{2}=0.875, \bar{R}^{2}=0.75$, F-statistic $=7.02$} & \multicolumn{4}{|c|}{$\mathrm{R}^{2}=0.94, \overline{\mathrm{R}}^{2}=0.80$, F-statistic $=6.92$} \\
\hline \multicolumn{4}{|c|}{$\begin{array}{l}\text { Wald test for Granger causality } \\
\text { Dependent Variable: } \mathrm{i}_{\text {a1t }}\end{array}$} & \multicolumn{4}{|c|}{$\begin{array}{l}\text { Wald test for Granger causality } \\
\text { Dependent Variable: } \mathrm{i}_{a 2 t}\end{array}$} \\
\hline Excluded & \multicolumn{2}{|c|}{ Wald test statistic $\left(x^{2}\right)$} & prob. & Excluded & \multicolumn{2}{|c|}{ Wald test statistic $\left(x^{2}\right)$} & prob. \\
\hline$M_{2 a t}$ & \multicolumn{2}{|l|}{14.18} & 0.00 & $M_{\text {2at }}$ & \multicolumn{2}{|l|}{13.57} & 0.00 \\
\hline$Y_{a t}$ & \multicolumn{2}{|l|}{8.08} & 0.04 & $Y_{t}$ & \multicolumn{2}{|l|}{9.87} & 0.01 \\
\hline$E_{a t}$ & \multicolumn{2}{|l|}{3.43} & 0.32 & $E_{t}$ & \multicolumn{2}{|l|}{3.57} & 0.31 \\
\hline$B_{t}$ & \multicolumn{2}{|l|}{7.48} & 0.05 & $B_{t}$ & \multicolumn{2}{|l|}{7.29} & 0.06 \\
\hline All: & \multicolumn{2}{|l|}{35.46} & 0.00 & All: & \multicolumn{2}{|l|}{30.42} & 0.00 \\
\hline
\end{tabular}

Source: Author's estimation

one-period lagged budget deficit raises interest rates. This positive impact supports the Keynesian view, although the budget deficit with a lag period of 2 years has a negative impact on the interest rate but is significant at the $10 \%$ level and can thus be ignored.

In each of the four cases, the dummy variable is significant, indicating that the change in the exchange rate regime has an impact on the macroeconomic relation that selected monetary and fiscal variables maintain interest rate levels. Nevertheless, the sign and the level of significance of the exchange rates coefficients are contradictory in the estimated models. Specifically, the role of the exchange rate change on interest rates is insignificant except in Estimation 1, where exchange rate change with a lag of two periods has a negative impact on the interest rate on 91-day TBs.

The insignificant and inconsistent impact of the exchange rate on interest rates is probably due to the pegged regime in Sri Lanka until 2000. Due to interventions and restrictions on the foreign exchange market under the pegged regime, the exchange rate fails to affect policy variables such as interest rates. Although since January 2001 Sri Lanka introduced an independent float regime, it is imperative to confirm whether 
the exchange rate in the flexible regime has any impact on interest rates when using quarterly time series.

Moreover, the computed values of the Wald test statistic corresponding to money growth in each of the four estimations establish that both M1 and M2 money growth Granger cause interest rates. This test also accepts the Granger causality running from income growth to interest rate, except in Estimation 3. However, the Wald test statistic corresponding to the exchange rate fails to accept the hypothesis of Granger causality from exchange to interest rate. The Wald test also establishes that the budget deficit Granger causes interest rates. In short, the Wald test of Granger causality confirms the causality from money growth, income growth, and budget deficit to interest rates in Sri Lanka over the study period.

The next step is to analyze the dynamics of interest rates using quarterly series over the post-global financial recession period. To this end, the VAR models are estimated using quarterly series of interest rates (call money rate and interest rate on 364-days TBs) and monetary factors. Similarly, the targeted equations are represented by Estimations 5-8 (Tables 5 and 6). In these estimations, a lag length of one is chosen based on the recommendations of a number of lag selection criteria, such SC, final prediction error, Hannan-Quinn information criterion. Moreover, the results of diagnostic tests of the estimated VAR are found satisfactory (but not reported due to space considerations).

The results in Table 5 indicate that income growth and exchange rate change have little impact on the call money rate (at the 10\% level), while M1 money growth has no such impact. Moreover, neither the M1money growth nor the income growth and exchange rate change have any impact on the interest rate on 364-day TBs. However, when the model is estimated replacing M1 by M2 money growth, the results are significantly different. In this case, a one period lagged M2 money growth raises both interest rates. This finding further supports the Fisher equation view for quarterly datasets in Sri Lanka. Further, a significant impact of income growth on the interest rate is found. However, unlike the estimations involving annual datasets, this impact is positive.

Table 5 Dynamics of interest rates involving quarterly dataset (M1 money growth is used)

\begin{tabular}{|c|c|c|c|c|c|c|c|}
\hline \multicolumn{4}{|c|}{ Targeted dependent variable $\mathrm{i}_{\mathrm{q} 1 \mathrm{t}}$ (of Estimation 5) } & \multicolumn{4}{|c|}{ Targeted dependent variable $\mathrm{i}_{\mathrm{q} 2 \mathrm{t}}$ (of Estimation 6) } \\
\hline Parameters & Estimates & t-values & Prob. & Parameters & Estimates & t-values & Prob. \\
\hline$\overline{a_{1}}$ & 0.164 & 0.870 & 0.39 & $a_{1}$ & 0.355 & 1.432 & 0.16 \\
\hline $\mathrm{i}_{q 1 \mathrm{t}-1}$ & 0.901 & 10.28 & 0.00 & $\mathrm{i}_{\mathrm{q} 2 \mathrm{t}-1}$ & 0.810 & 7.447 & 0.00 \\
\hline$M_{1 q t-1}$ & 0.500 & 1.605 & 0.12 & $M_{1 q t-1}$ & 0.527 & 0.953 & 0.37 \\
\hline$Y_{\mathrm{qt}-1}$ & 0.843 & 1.947 & 0.06 & $Y_{\mathrm{qt}-1}$ & 1.254 & 1.552 & 0.13 \\
\hline$E_{q t-1}$ & 1.016 & 1.811 & 0.08 & $E_{q t-1}$ & 1.384 & 1.333 & 0.19 \\
\hline \multicolumn{4}{|c|}{$R^{2}=0.83, \bar{R}^{2}=0.80$, F-statistic $=29.63$} & \multicolumn{4}{|c|}{$R^{2}=0.746, \bar{R}^{2}=0.703$, F-statistic $=17.64$} \\
\hline \multicolumn{4}{|c|}{$\begin{array}{l}\text { Wald test for Granger causality } \\
\text { Dependent Variable: } \mathrm{i}_{\mathrm{q} 1 \mathrm{t}}\end{array}$} & \multicolumn{4}{|c|}{$\begin{array}{l}\text { Wald test for Granger causality } \\
\text { Dependent Variable: } \mathrm{i}_{\mathrm{q} 2 \mathrm{t}}\end{array}$} \\
\hline Excluded & \multicolumn{2}{|c|}{ Wald test statistic $\left(x^{2}\right)$} & prob. & Excluded & \multicolumn{2}{|c|}{ Wald test statistic $\left(x^{2}\right)$} & prob. \\
\hline$M_{1 q t}$ & \multicolumn{2}{|c|}{2.577} & 0.10 & $M_{1 q t}$ & \multicolumn{2}{|c|}{0.816} & 0.36 \\
\hline$Y_{q t}$ & \multicolumn{2}{|l|}{3.391} & 0.05 & $Y_{\mathrm{qt}}$ & \multicolumn{2}{|l|}{2.408} & 0.12 \\
\hline$E_{q t}$ & \multicolumn{2}{|l|}{3.283} & 0.07 & $E_{q t}$ & \multicolumn{2}{|l|}{1.776} & 0.18 \\
\hline All: & \multicolumn{2}{|l|}{17.73} & 0.05 & All: & \multicolumn{2}{|l|}{4.248} & 0.23 \\
\hline
\end{tabular}

Source: Author's estimation 
Table 6 Dynamics of interest rates involving quarterly dataset: (M2 money growth is used)

\begin{tabular}{|c|c|c|c|c|c|c|c|}
\hline \multicolumn{4}{|c|}{ Targeted dependent variable $\mathrm{i}_{\mathrm{q} 1 \mathrm{t}}$ (of Estimation 7) } & \multicolumn{4}{|c|}{ Targeted dependent variable $\mathrm{i}_{\mathrm{q} 2 \mathrm{t}}$ (of Estimation 8) } \\
\hline Parameters & Estimates & t-values & Prob. & Parameters & Estimates & t-values & Prob. \\
\hline$a_{1}$ & 0.127 & 0.816 & 0.42 & $a_{3}$ & 0.257 & 1.220 & 0.23 \\
\hline $\mathrm{i}_{\mathrm{q} 1 \mathrm{t}-1}$ & 0.891 & 12.517 & 0.00 & $\mathrm{i}_{\mathrm{q} 2 \mathrm{t}-1}$ & 0.814 & 9.041 & 0.00 \\
\hline$M_{2 q t-1}$ & 2.205 & 3.299 & 0.00 & $M_{2 q t-1}$ & 3.269 & 2.562 & 0.01 \\
\hline$Y_{\mathrm{qt}-1}$ & 0.722 & 1.902 & 0.06 & $Y_{q t-1}$ & 1.071 & 1.465 & 0.15 \\
\hline$E_{q t-1}$ & 1.399 & 2.759 & 0.01 & $\mathrm{E}_{\mathrm{qt}-1}$ & 2.066 & 2.118 & 0.04 \\
\hline \multicolumn{4}{|c|}{$R^{2}=0.871, \bar{R}^{2}=0.850$, F-statistic $=40.77$} & \multicolumn{4}{|c|}{$R^{2}=0.793, \bar{R}^{2}=0.759$, F-statistic $=23.11$} \\
\hline \multicolumn{4}{|c|}{$\begin{array}{l}\text { Wald test for Granger causality } \\
\text { Dependent Variable: } \mathrm{i}_{\mathrm{q} 1 \mathrm{t}}\end{array}$} & \multicolumn{4}{|c|}{$\begin{array}{l}\text { Wald test for Granger causality } \\
\text { Dependent Variable: } \mathrm{i}_{\mathrm{q} 2 \mathrm{t}}\end{array}$} \\
\hline Excluded & \multicolumn{2}{|c|}{ Wald test statistic $\left(x^{2}\right)$} & prob. & Excluded & \multicolumn{2}{|c|}{ Wald test statistic $\left(x^{2}\right)$} & prob. \\
\hline$M_{2 q t}$ & \multicolumn{2}{|l|}{10.89} & 0.00 & $M_{2 q t}$ & \multicolumn{2}{|l|}{6.564} & 0.01 \\
\hline$Y_{\mathrm{qt}}$ & \multicolumn{2}{|l|}{3.617} & 0.05 & $Y_{\mathrm{qt}}$ & \multicolumn{2}{|l|}{2.149} & 0.14 \\
\hline$E_{q t}$ & \multicolumn{2}{|l|}{7.614} & 0.00 & $E_{q t}$ & \multicolumn{2}{|l|}{4.489} & 0.03 \\
\hline All: & \multicolumn{2}{|l|}{17.73} & 0.00 & All: & \multicolumn{2}{|l|}{10.79} & 0.01 \\
\hline
\end{tabular}

Source: Author's estimation

Additionally, a one quarter lagged exchange rate change causes a rise in interest rates. The exchange rate in this analysis is the spot Sri Lankan rupee/US dollar for the period when the flexible exchange rate was operational in the country. Therefore, a positive change of this exchange rate means currency depreciation. Moreover, a positive impact of this exchange rate on the interest rate, particularly under the flexible regime, supports the theoretical fact that a decrease in the exchange rate causes a rise in export, which in turn increases income. The higher income (or income growth) have a positive impact on interest rates. These results are further supported by the Wald test (reported in the lower part of each table) and are robust.

Having confirmed the causal impact of the selected monetary and fiscal variables on interest rates, this paper now investigates the dynamic movement of interest rates due to endogenous innovations of the estimated VAR. Impulse response analysis has been carried, being useful for studying the dynamic interactions between the variables of the estimated VAR model. The time plots of the impulse response function of interest rate on 91-day TBs due to the innovations of M1 money growth, come growth, changes in exchange rate, and budget deficit are presented in Fig. 2. Again, the impulse response function of the same interest rate due to the innovations of M2 money growth, income growth, changes in exchange rate, and budget deficit is presented in Fig. 3. The impulse response functions of interest rates on 364-day TBs are similar to the interest rate on 91-day TBs and are thus not reported.

From the impulse response functions of the annual interest rate on 91-day TBs reported in Figs. 2 and 3, the following inferences are drawn:

(i) Impulses transmitted through the interest rate channel causes an immediate rise in interest rate, but gradually pull back to the base level;

(ii) Interest rates reach a high level due to the impulses transmitted through both M1 andM2 money growth channels and lead to periodic fluctuations around the base level before abolition. Here, the impulse of M2 money growth appears to be stronger than that of M1 as it causes a higher increase in the interest rate; 


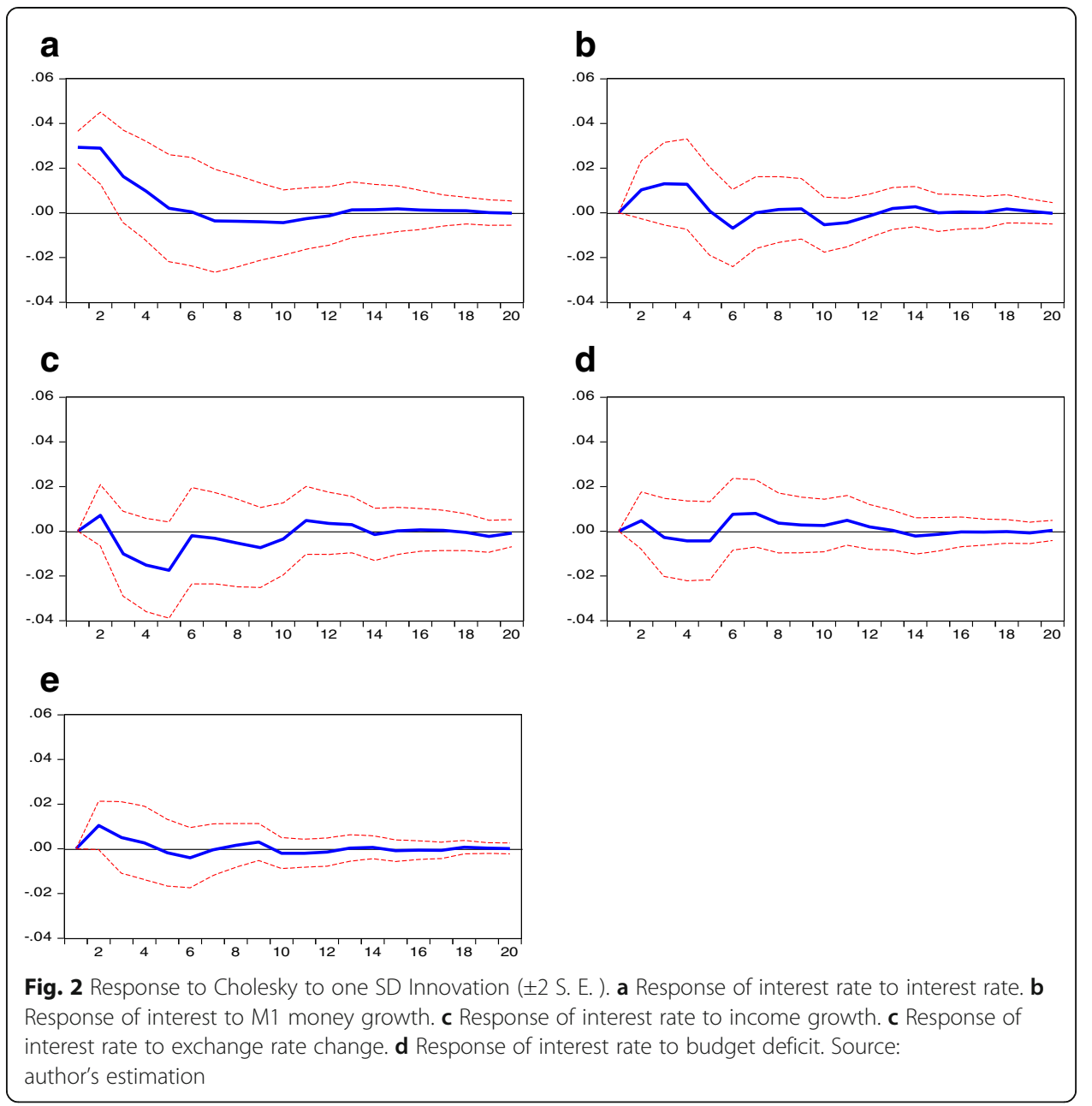

(iii) Impulses transmitted through the income growth channel push the interest rate below the base line over a long period;

(iv) A small fluctuation of the interest rate is observed due to impulses transmitted through the exchange rate channel;

(v) Impulses transmitted through the budget deficit channel push up interest rate in the initial period and cause small fluctuations.

Finally, the impulse response functions of the call money rate due to the innovations transmitted through M2money growth, income growth, and exchange rate change are presented in Fig. 4. This response is somewhat different compared to the response of annual interest rates explained earlier. In this case, innovations of each of the three determinants of the interest rate have succeeded to an immediate rise in the call money rate, which persists for a longer period. Among these three innovations, the exchange rate innovation is the most severe in pushing up interest rate to the highest level, followed by the money and income growth innovations. The nature of the impulse response function of quarterly 364-day TBs is similar to that of the call money rate and is thus not presented. The impulse response analysis based on the estimated VAR using M1 money growth (and other variables) is 


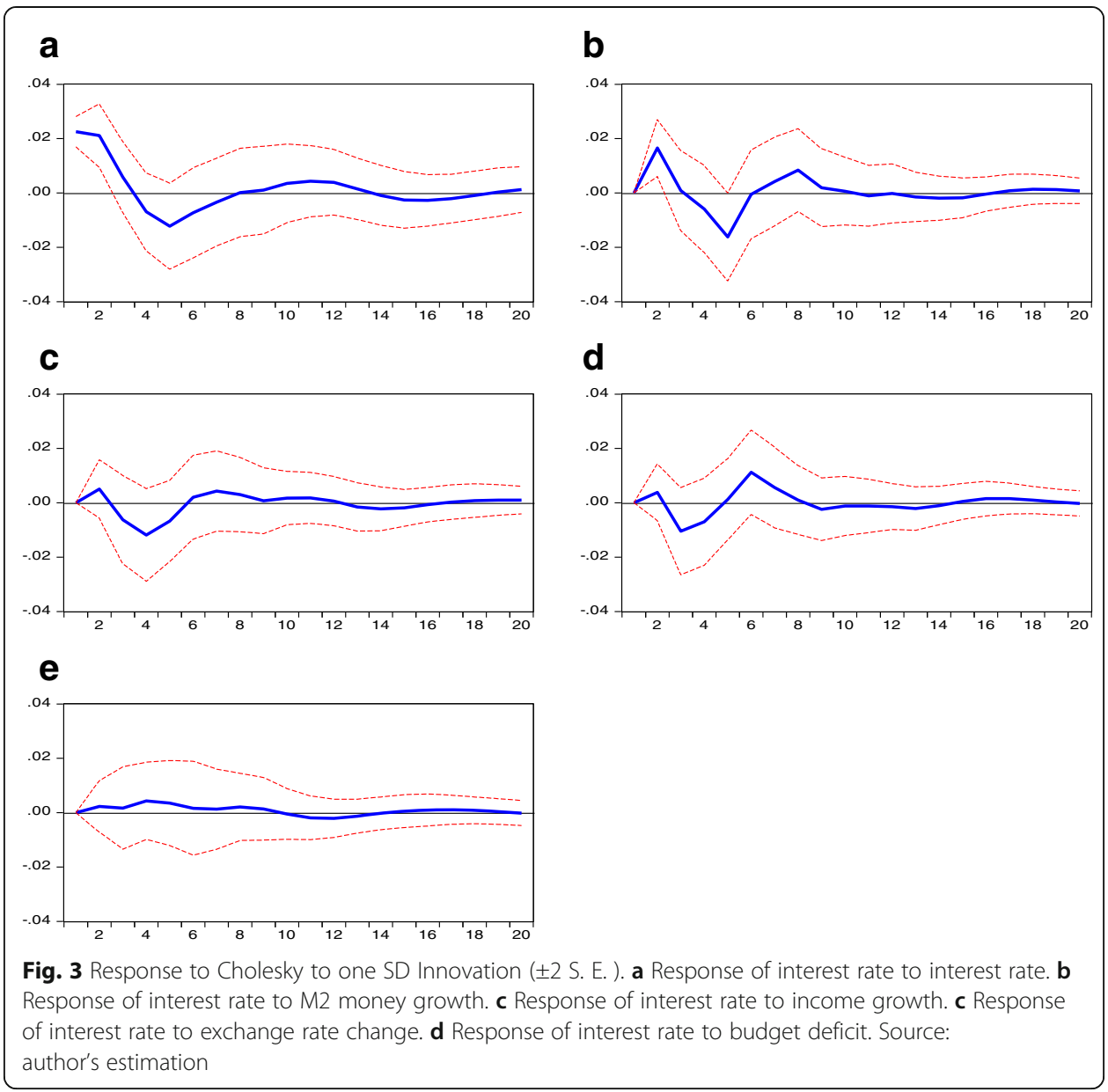

also not reported since most parameters estimated in this VAR are insignificant. Therefore, the impulse response analysis reveals that, in the post-recession independent float exchange rate regime, the exchange rate has a stronger role in the variations of interest rate compared to the other determinants such as money and income growth.

\section{Conclusion}

This paper studies the role of certain monetary and fiscal factors in the variations of nominal interest rates in Sri Lanka over the period 1983-2015, when the interest rates were deregulated. The first part of the empirical analysis uses an annual time series dataset, including interest rates on 91-day and 364-day TBs, growth of the narrow money M1, the broad money M2, income growth, changes in nominal exchange rate, and budget deficit. To confirm whether the change in exchange rate regime (from the pegged to market based) over the study period affects the macroeconomic relation under investigation; a dummy variable is also included. Using a quarterly dataset, the second part of the paper analyzes the role of monetary factors in the variations of the call money rate and interest rate on 364-day TBs during the post-global recession period. The causal role of the selected factors on the variation of interest rates is analyzed using a VAR model, followed by the Wald tests of Granger causality. Additionally, 

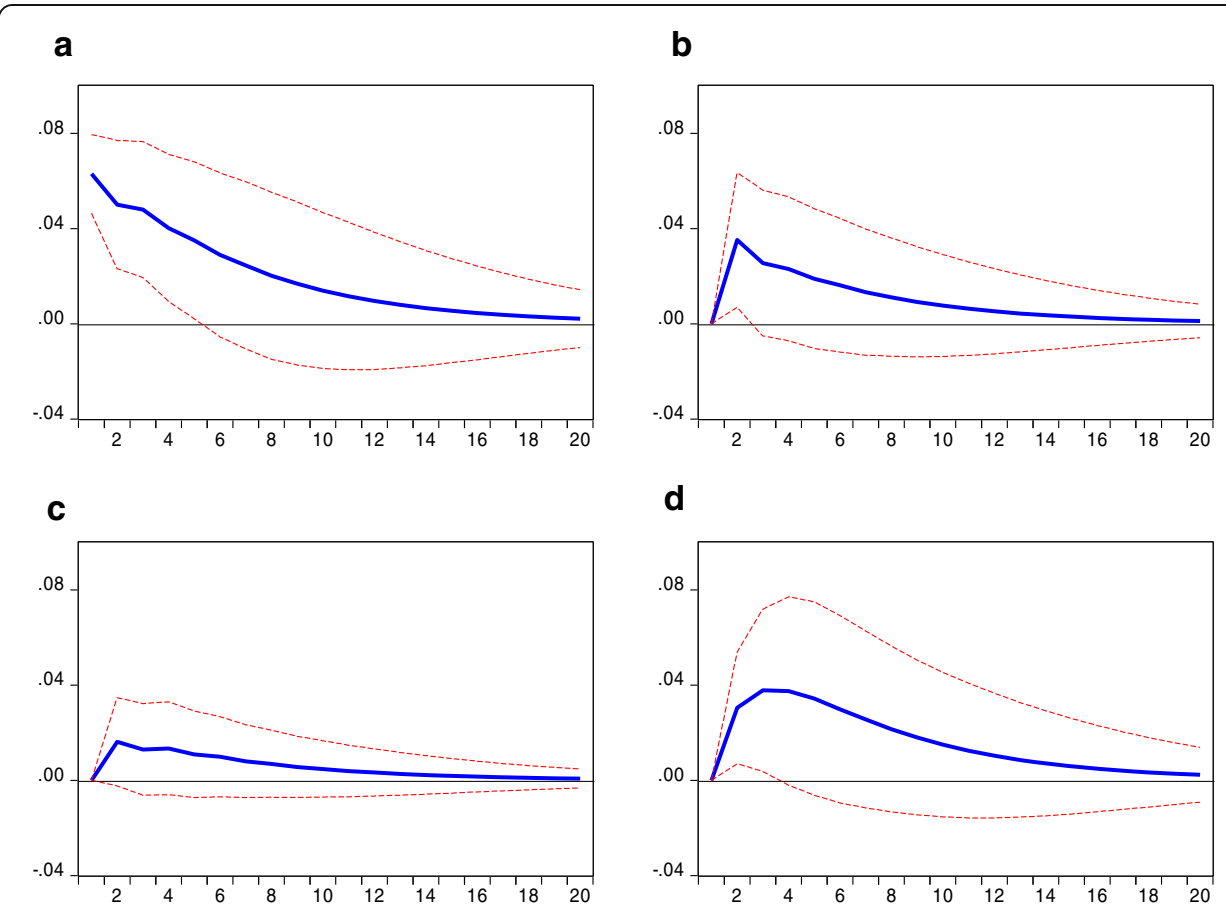

\section{d}

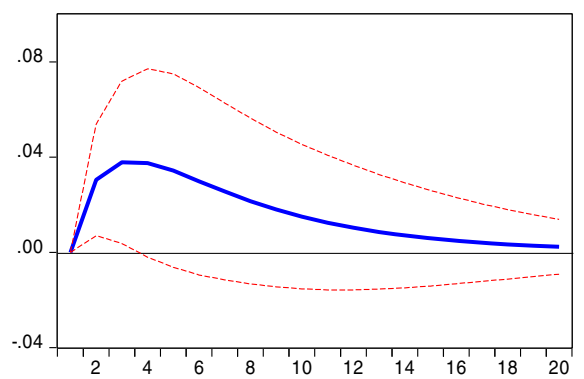

Fig. 4 Response to Cholesky to one SD Innovation ( \pm 2 S. E. ). a Response of call rate to call rate. $\mathbf{b}$ Response of call rate to M2 money growth. c Response of call rate to income growth. $\mathbf{d}$ Response of call rate to exchange rate change. Source: author's estimation

impulse response analysis is used to trace the dynamic impact of interest rates due to the endogenous innovations of monetary and fiscal factors.

The paper finds that, among the selected determinants, both M1 and M2 money growth cause interest rates to rise, supporting the Fisher equation view. On the other hand, the impact of income growth is negative, which is consistent with the positive impact of money growth on interest rates. The budget deficit causes interest rates to rise, which supports the Keynesian view. However, the role of the exchange rate on interest rate variations is almost insignificant and contradictory. This insignificant impact of exchange rate on interest rates reflects the overall impact of the two different exchange rate regimes in Sri Lanka over the analyzed period. This is also supported by the statistically significant estimate of the dummy variable, indicating that the change in exchange rate regime affects the relation that interest rates have maintained with monetary and fiscal factors.

Moreover, over the post-global recession period, the positive causal role of broad money growth on interest rates is re-established. Further, a significant impact of income growth is also found. Furthermore, a prominent role of exchange rate on interest rate is established where exchange rate depreciation in the flexible regime causes an increase in interest rates. Therefore, the exchange rate affects interest rates significantly when a flexible exchange rate system is introduced.

This paper has certain policy implications. As the interest rate is influenced by both monetary and fiscal factors, it would be effective to manage the interest rate through judicious monetary and the fiscal policy management. The significant effect of the exchange rate on interest rate during the post-global recession period (when the flexible 
exchange rate system was operational) suggests that, apart from the domestic factors, some external factors (typically transmitted through the exchange rate channel) could play a role in the variation of interest rates. However, further analysis is required in this direction. Another limitation of the paper is the short time span of the analysis. However, the reliability of estimations is verified with the limited degrees of freedom. Nevertheless, a study of the structural change in the dynamics of interest rates due to the monetary and fiscal determinants may provide further insights as a future research topic.

Acknowledgements

Author would like to thank the anonymous Reviewers of the journal for their comments on paper. Some of the comments help to improve the paper.

\section{Funding}

The author has received no funding for this research.

\section{Authors' information}

The author is an Assistant Professor at the Department of Economics, University of Gour Banga, West Bengal, India.

\section{Competing interests}

The author declares that he has no competing interests.

Received: 22 April 2017 Accepted: 20 October 2017

Published online: 31 October 2017

\section{References}

Abubakar J, Sivagnanam KJ (2016) Fisher's effect: an empirical examination using India's time series data. J Quant Econ. doi:10.1007/s40953-016-0065-0

Ahmad M, Karim MZA (2011) Interest rate determination and the effect of Asian financial crisis in Malaysia. IUP J Appl Econ 10(1):37-54

Ahn BC (1994) Monetary policy and the determination of the interest rate and exchange rate in a small open economy with increasing capital mobility, Federal Reserve Bank of St. Louis working paper series no. 024A. Federal Reserve Bank of St. Louis, St. Louis

Aisen A, Hauner D (2008) Budget deficits and interest rates: a fresh perspective, IMF working paper, WP/08/42. International Monetary Fund, Washington, D.C.

Akhtar MA (1995) Monetary policy and long-term interest rates: a survey of empirical literature, contemporary economic policy 13(3):110-130. doi:10.1111/j.1465-7287.1995.tb00727.x

Aksoy Y, León-Ledesma MA (2005) Interest rates and output in the long-run, Working paper, no. 434/January 2005 European Central Bank, 60311 Frankfurt am Main, Germany.

Amarasekara C (2005) Interest rate pass-through in Sri Lanka. Staff Stud Cent Bank Sri Lanka 35(1\&2):1-32. 10.4038/ss. v35i.1232

Amarasekara C (2008) The impact of monetary policy on economic growth and inflation in Sri lank. Staff Stud Cent Bank Sri Lanka 38(1\&2):1-44. doi: 10.4038/ss.v38i1.1220

Asamoah LA, Adu G (2016) An empirical analysis of the determinants of interest rates in Ghana. J Afr Bus 17(3):377-396. doi:10.1080/15228916.2016.1207493

Bernanke BS, Mihov I (1998) The liquidity effect and long-run neutrality. In: Carnegie-Rochester conference series on public policy, vol 49, pp 149-194

Bhanumurthy NR, Agarwal S (2003) Interest rate-price nexus in India. Indian Econ Rev 38(2):189-203

Bhattacharya BB, Bhanumurthy NR, Mallick H (2008) Modeling interest rate cycle in India. J Policy Model 30(5):899-915. doi:10.106/j.jpolmod.2007.03.004

Caporale GM, Pittis N (1997) Domestic and external factors in interest rate determination. Appl Financ Econ 7(5):465471. doi:10.1080/09603109733321

Cooray A (2002) Interest rates and inflationary expectations: evidence on the fisher effect in Sri Lanka. South Asia Econ J 3(2):201-216. doi: 10.1177/139156140200300205

Dickey DA, Fuller WA (1981) Likelihood ratio statistics for autoregressive time series with a unit root. Econometrica 49(4):1057-1072

Dua P, Pandit BL (2002) Interest rate determination in India: domestic and external factors. J Policy Model 24(8):853875. doi:10.1016/S0161-8938(02)00172-2

Edwards S, Khan MS (1985) Interest rate determination in developing countries. IMF Staff Pap 32(3):377-403. doi: $10.3386 /$ w1531.

Engen E, Hubbard RG (2004) Federal Government Debts and interest rates, NBER working paper 10681. National Bureau of Economic Research, Cambridge

Evans P (1987) Interest rates and expected future budget deficits in the United States. J Polit Econ 95(11):32-58. doi:10.1016/0304-3932(87)90020-1.9

Feldstein MS (1986) Budget deficits, tax rules, and real interest rates, NBER working paper 1970. National Bureau of Economic Research, Cambridge

Fisher I (1930) The theory of interest. Macmillan, New York

Fleming JM (1962) Domestic financial policies under fixed and under floating exchange rates. Staff Papers 9(3):369-380 
Goh SK, Alias MH (2002) Malaysia financial liberalization and crisis: reflections on national responses. In: Tan AHH (ed) Monetary and Financial Management in Asia in the 21st century. World Scientific Publishing Co. Pvt. Ltd, Singapore, pp 191-211

He D, Wang H, Yub X (2014) Interest rate determination in China: past, present, and future. Int J Cent Bank 11(4):255-277

Howe H, Pigott C (1991) Determinants of long-term interest rates: an empirical study of several industrial countries. Fed Reserve Bank N Y Q Rev 16(4):12-28

Jayasinghe, P. and T. Udayaseelan (2010) Does Fisher Effect Hold in Sri Lanka? An Analysis with Bounds Testing Approach to Cointegration. Available at: http://dx.doi.org/10.2139/ssrn.2534917.

Kameda K (2014) Budget deficits, government debt and long-term interest rates in Japan. J Jpn Int Econ 32:105-124. doi: 10.1016/jjie.2014.02.001

Keynes JM (1936) The general theory of employment, interest and money. Macmillan Cambridge University Press, for Royal Economic Society in 1936

Knot K (1995) On the determination of real interest rates in Europe. Empir Econ 20(3):479-500

Laubach T (2009) New evidence on the interest rate effects of budget deficits and debt. J Eur Econ Assoc 7(4):858-885. doi: 10.1162/JEEA.2009.7.4.858

Maitra B (2017) Determinants of nominal interest rates in India. J Quant Econ. doi: 10.1017/s40953-017-0079-2

Maitra B, Debnath S (2015) Efficacy of recent monetary policy in Sri Lanka. Int J Econ Bus Res 10(4):341-361. doi: 10. 1504/IJEBR.2015.072504

Monnet C, Weber WE (2001) Money and interest rates, Federal Reserve Bank of Minneapolis. Q Rev 25(4):2-13

Mundell RA (1963) Capital mobility and stabilization policy under fixed and flexible exchange rates. Can J Econ Polit Sci 29(4):475-485

Nachane DM (1988) The interest-price nexus: an old theme revisited. Econ Polit Wkly 23(9):421-424

Paul MT (1984) Interest rates and fisher effect in India. Econ Lett 14(1):17-22. doi: 10.1016/0165-1765(84)90022-3

Phillips PCB, Perron P (1988) Testing for a unit root in a time series regression. Biometrika 75(2):335-346

Plosser C (1982) Government financing decisions and asset returns. J Monet Econ 9(3):325-352. doi: 10.1016/03043932(82)90022-8

Plosser C (1987) Fiscal policy and the term structure. J Monet Econ 20(2):343-367

Quigley MR, Porter-Hudak S (1994) A new approach in analyzing the effect of deficit announcements on interest rates. J Money Credit Bank 26(4):894-902

Schabert A (2005) Money supply and the implementation of interest rate targets, Working paper series, no. 483, may 2005. European Central Bank, 60311 Frankfurt am Main, Germany.

Thorbecke W (1993) Why deficit news affects interest rates. J Policy Model 15(1):1-11

Turtelboom B (1991) Interest rate liberalization: some lessons from Africa, IMF working paper, no. WP/91/121. International Monetary Fund, Washington DC

Wachtel P, Young J (1987) Deficit announcements and interest rates. Am Econ Rev 77(5):1007-1012

Submit your manuscript to a SpringerOpen ${ }^{\circ}$ journal and benefit from:

- Convenient online submission

- Rigorous peer review

Open access: articles freely available online

High visibility within the field

Retaining the copyright to your article

Submit your next manuscript at $>$ springeropen.com 